\title{
PERFORMANCE IMPLICATIONS OF DIVERSIFICATION STRATEGIES DURING INSTITUTIONAL TRANSFORMATIONS: AN EMERGING MARKET STUDY
}

\author{
Srinivasan, S. ${ }^{1}$, Thenmozhi, M. ${ }^{2}$ and Vijayaraghavan, P. $^{3}$ \\ ${ }^{1}$ Great Lakes Institute of Management, Chennai \\ E-mail: sur9999sur@yahoo.com \\ ${ }^{2}$ Department of Management Studies, Indian Institute of Technology, Madras \\ E-mail:mtm@iitm.ac.in \\ ${ }^{3}$ Department of Management Studies, Indian Institute of Technology, Madras \\ E-mail: vijayaraghavan.p@gmail.com
}

\begin{abstract}
The purpose of this study is to develop a comprehensive model that examines the impact of corporate diversification, and its interaction effects with ownership structure, industry structure and firm size, to explain firm performance for three distinct phases of institutional development in an Indian context. The conceptual model developed through a review of literature is tested using a large sample of publicly traded companies in India, using the GLM Univatiate model for Post-liberalization, Transition and Pre-liberalization phases that span a period of fifteen years. Our findings show that diversification firm performance relationship varies as institutions develop. Although unrelated diversifiers achieved superior performance during the pre-liberalization phase, focused players performed better during the transition phase. In the Post-liberalization phase, diversification did not impact firm performance; superior firm performance was driven by the ability of firms to scale, be present in profitable industries and productively use their assets. Significant interaction effects were observed between diversification and, industry structure, ownership type and firm size, in explaining firm performance. Firms affiliated to large business groups continue to be highly diversified and under performed as institutions developed.
\end{abstract}

Keywords: corporate diversification, ownership structure, industry structure, firm size, firm performance, institutional transformation

$\underline{\text { ARTICLE INFO }}$

Article History:

Received: 20 March 2020

Accepted: 12 July 2020

Published: 31 December 2020 


\section{INTRODUCTION}

Corporate Diversification in general, and more specifically in firms affiliated to large business groups in emerging markets, is a subject of enormous interest to both the academia and practice (Wang, Chen, Guo, \& Lin, 2019). Although the research on corporate diversification and firm performance relationship spans decades (Mackey, Barney, \& Dotson, 2017; Schommer, Richter, \& Karna, 2019), it has failed to generate consistent findings that could be generalized (Zahavi \& Lavie, 2013) across nations and contexts (Mayer \& Whittington, 2003; Yigit \& Behram, 2013).

In developed economies contexts unrelated diversification attracts 'diversification discount' (Mackey et al., 2017; Santalo \& Becerra, 2008; Ammann, Hoechle, \& Schmid, 2012), but enhances firm performance in emerging economies (Ramaswamy, Li, \& Veliyath, 2002; Chakrabarti, Singh, \& Mahmood, 2007). Contrastingly, highly diversified firms even in developed economies do demonstrate superior firm performance (Campa \& Kedia, 2002; Anand \& Jayanthi, 2005). Even within the emerging economies, diversification performance relationship cannot be generalized across nations due to differences in institutional contexts (Khanna \& Palepu, 2000; Ramaswamy et al., 2002; North, 1993; Chen $\& \mathrm{Chu}, 2012)$, and within nations, across time periods where institutions develop over time (Mayer \& Whittington, 2003; Benito-Osorio, AngelGuerras-Martin, \& Angel Zuniga-Vicente, 2012, Yigit \& Behram, 2013). Emerging economies cannot be clubbed into one group, as the extent of institutional development varies, making it difficult to generalize 'a priori' diversification performance relationship (Chakrabarti et al., 2007). Whether or not unrelated diversification have a positive impact on firm performance, depends on the level of institutional development in the national context; in weaker institutions, unrelated diversification will positively impact firm performance (Wan, 2005; Lee, Peng, \& Lee, 2008).

Extensive family ownership and group affiliation of firms also contribute to the uniqueness of diversification performance relationship in emerging markets (Ma, Yao, \& Xi, 2006). Firms affiliated to large business groups are highly diversified and are well positioned to achieve superior performance by taking advantage of economies of scale and scope (Piskorski, 2005; Anand, 2005; Anand \& Jayanthi, 2005). Their ability to 
internalize institutional voids in the economy by creating internal labor, product and capital markets provides them a competitive advantage (Bae, Kwon, \& Lee, 2008). Also their scale enables them to gain proximity to regulators, which also helps them garner larger share of scarce economic resources, depriving the competition (Wan, 2005). However, when such group affiliated firms continue to remain unrelatedly diversified in spite of institutions developing and with focused competition setting in over time, the competitive advantages which such firms enjoyed wane out resulting in diversification discount (Basu, 2010; Wan, 2005). Further, ownership structure in terms of shareholder concentration also has an impact on the diversification firm performance relationship (Amihud \& Lev, 1981; George, 2007; Aguilera, Desender, Bednar, \& Lee, 2015).

Diversification firm performance relationship varies with business cycles, periods of industry distress, recession and economy wide shocks, which further makes such relationship highly unpredictable that cannot be generalized (Volkov \& Smith, 2015; Gopalan \& Xie, 2011; Chakrabarti et al., 2007). Further, industry structure (Montgomery, 1981) and firm size (Peng \& Heath, 1996) impacts diversification firm performance relationship. Managerial depth (Prahalad \& Bettis, 1986), organizational structure (Klein $\&$ Saidenberg, 2010) and certain idiosyncratic capabilities to handle higher levels of diversity also varies in firms which have performance implications as institutions develop (Campa \& Kedia, 2002).

Theoretical motivation for this study stems from fusing the Resource Based Theory (Barney, 1991, 1992; Barney \& Griffin, 1992) and the Institutional Theory (North, 1993; Wan, 2005; Chen \& Chu, 2012), where we explored the performance implications of diversified firms, including those affiliated to large business groups, during institutional transformation in an emerging market context. Our study incrementally contributes in many ways. First, our study builds a comprehensive model that links corporate diversification, ownership structure, industry structure, firm size and firm performance in varying contexts of institutional development within the same national setting, examining their direct and interaction effects. Second, while many studies take into account only the total diversification component (Singh, Nejadmalayeri, \& Mathur, 2007), we have captured both the extent and direction of diversification. Third, the hypotheses we developed in this study was tested using a large sample of publicly traded companies 
in India. With substantial institutional development over a short span of time (Mohan, 2007), India is considered to be an appropriate setting to empirically test the research propositions. The study was conducted in three distinct phases with varying institutional development; pre-liberalization phase, transition phase and post-liberalization phase; the hypotheses were tested separately for the three phases. The rest of the paper is structured as follows. Section 2 sets out the literature review. Section 3 describes the data and methodology. Section 4 explains the results. Sections 5 present the conclusion and managerial implications. Section 6 sets out the limitations of the study and the scope for future research.

\section{LITERATURE REVIEW}

The resource based view argues that competitive advantage stems from unique and idiosyncratic resources which are valuable, rare, inimitable and non-substitutable (Barney, 1991, 1992; Barney \& Griffin, 1992). Corporate diversification is the means by which firms leverage such unique firm specific capabilities into related and unrelated markets to achieve competitive advantage (Piskorski, 2005). The central question in corporate diversification research is which type of diversification yields superior firm performance, and in what contexts (Markides \& Williamson, 1994). We have strong evidence from the Western literature that diversification strategy of moving into areas that are far away from one's core competence is value destroying (Rumelt, 1974; Bettis, 1981; Lecraw, 1984; Varadarajan, 1986; Varadarajan \& Ramanujam, 1987). However, scholars show that such a strategy may not be inappropriate in an emerging market scenario (Ramaswamy et al., 2002; Ghemawat, 2007). This view is in line with the literature which confirms that diversification firm performance relationship is not robust across nations due to differences in the institutional context (Gedajlovic \& Shapiro, 1988; Bensaou et al., 1999) as well as they are not robust across time periods within the same national context (Grant \& Jammine, 1988; Palich, Cardinal, \& Miller, 2000).

In a developed economy context, where institutions are well developed, unrelated diversification attracts 'diversification discount' arising out of lack of synergies between the portfolios of unrelated businesses (Wan, 2005; Anand \& Jayanthi, 2005; Mackey et al., 2017; Santalo \& Becerra, 2008; 
Ammann et al., 2012). Also, diversified firms fail to match up with focused players competing directly on 'market based' capabilities like research and development (R\&D), marketing and innovation capabilities (Wan, 2005). While studies show related diversification result in improved performance resulting from sharing of resources across related businesses and cross selling among businesses (Anand \& Jayanthi, 2005), other studies also show a negative relationship (Li \& Greenwood, 2004).

In emerging economies, where external markets for product, labor and capital fail, diversified large business groups may find it beneficial to create 'internal markets' through unrelated diversification and thereby circumvent external market failures. In effect, Ramaswamy et al. (2002) and Chen and Ho (2000) argue that unrelated diversification may be value-adding in emerging markets where the institutional context remains underdeveloped and is marred with market failures. Diversified firms could create and exploit market power advantages, for example in selling their products and buying raw materials (Amit \& Livnit, 1988). Diversification positively impacts firm performance when benefits of diversification exceed its cost (Chen \& Chu, 2012; Bae et al., 2008). In emerging market contexts, where institutional development is low, unrelated diversification is beneficial (Ramaswamy et al., 2002; Chakrabarti et al., 2007) as firms build 'non market based' capabilities (Wan, 2005), i.e., internalizing failed external institutions that reduces transaction costs and gaining proximity to regulators (Khanna \& Palepu, 2000). Such benefits exceed costs of unrelated diversification that includes agency costs and complexity in managing the diversified business (Anand \& Jayanthi, 2005). However, research in emerging market contexts has also provided inconsistent results. The study of Singaporean companies showed that with low institutional development and market failures, diversification adds value to shareholders (Chen \& Ho, 2000) while other studies showed a negative relationship (Baek, Lee, Lee, \& Mohanty, 2018; George 2007). Pawaskar's (1999) Indian study showed that diversification performance relationship depended on the asset utilization of firms. The study of Srinivasan, Thenmozhi, and Vijayaraghavan (2006) showed no significant relationship as favorable industry conditions masked inefficiencies in unrelated diversification. The review of literature hence provides inconclusive and contradictory results. Hence our first hypothesis is: 
$\mathbf{H}_{\mathbf{0 1}}$ : There will be no impact of corporate diversification on firm performance, after considering ownership structure, industry structure and firm size, for each of the time periods.

Ownership type and shareholder concentration are both important variables to be considered when examining diversification firm performance relationship. The ownership structure and firm performance relationship has been examined in the literature in terms of ownership type and performance relationship and shareholder concentration and performance relationship, separately. The ownership type of a firm impacts firm's risk return expectations (Alchian \& Demstez, 1972), diversification strategies pursued by the firm (Ramaswamy et al., 2002) and on firm performance (Thomsen \& Pedersen, 2000). In the emerging market context, group affiliated and family owned firms gain competitive advantage through unrelated diversification (Khanna \& Palepu, 1997, 2000; Ma et al., 2006) which helps them build scale, 'non market' capabilities and regulatory proximity (Wan, 2005). The board structure in family owned firms also leads to conflict and inefficiency in the company particularly regarding the oversight of strategic decisions (Amrah \& Obaid, 2019). However, as institutions develop, such an advantage wanes away (Lee et al., 2008; Chen $\& \mathrm{Chu}, 2012)$. Although group affiliated firms are highly diversified, they destroy shareholder value (Kakani, 2002; Singh et al., 2007; Kakani, 2000) as a result of internal power struggles and poor resource allocation (Rajan, Servaes, \& Zingales, 2000), poor knowledge and resource integration (Li \& Wong, 2003) and increased managerial complexity (Chen \& Chu, 2012) pushing up costs of diversification.

Higher levels of shareholder concentration, i.e., presence of large block shareholders, reduce agency behavior of managers through better oversight, thereby reducing the level of firm's unrelated diversification and improving firm performance (Amihud \& Lev, 1981; Jensen, 1986; Hoskisson $\&$ Turk, 1990). Low shareholder concentration results in managers not monitored by large block shareholders, thereby providing a scope for managers to pursue value-destroying unrelated diversification strategies to further their own interests, destroying shareholder value (Denis, Denis, \& Sarin, 1997; Hope \& Thomas, 2008). Contrastingly, the positive effect manager's bring to the business through reputational effects reduces agency conflict (Hoskisson \& Turk, 1990). In emerging market contexts a high 
level of shareholder concentration mitigates excessive diversification and increases firm performance (George, 2007). With an increase in institutional development over time, external governance mechanisms that include the legal environment, market for corporate control, external auditors, stakeholder activism, rating organizations and media, will complement internal governance mechanisms to force managers to create shareholder value (Aguilera et al., 2015) by winding down the level of unrelated diversification (Hoechle, Schmid, Walter, \& Yermack, 2012). Thus our next null hypothesis follows:

$\mathbf{H}_{\mathbf{0} 2}$ : There will be no impact of ownership structure, in terms of ownership type and shareholder concentration, on firm performance, for each of the time periods.

$\mathbf{H}_{02 \mathbf{a}}$ : There will be no interaction effects between ownership structure, in terms of ownership type and shareholder concentration, and corporate diversification in explaining firm performance, for each of the time periods

There is a strong linkage between industry structure and firm performance. Montgomery (1981) found that diversified firms with higher levels of performance tended to be positioned in industries with favorable industry structures. While researchers put forth exploitation of market power as an advantage of diversification, others argue that diversified firms have significantly lower market power in their respective markets (Montgomery, 1981). Even in the landmark study of Rumelt (1991) that showed a positive diversification performance relationship, industry structure effects dominated such superior performance (Schmalensee, 1985). Some researchers found no impact of industry factors on firm performance (Hawawini, Subramanian, \& Verdin, 2003). Industry profitability, industry concentration (Santalo \& Becerra, 2008) and market share (Hill \& Snell, 1988) are reflective of the industry structure that impacts firm performance (Kwoka, 1981). Changes in industry conditions, recession and economy wide shocks resulting from business cycles negatively impact firm performance (Chakrabarti et al., 2007) and this will impact the diversification performance relationship (Gopalan \& Xie, 2011; Volkov \& Smith, 2015). Hence our null hypothesis follows: 
$\mathbf{H}_{03}$ : There will be no impact of industry structure, in terms of industry profitability, industry concentration and market share, on firm performance, for each of the time periods.

$\mathbf{H}_{\mathbf{0 3 a}}$ : There will be no significant interaction effects between industry structure, in terms of industry profitability, industry concentration and market share, and corporate diversification in explaining firm performance.

Size provides economies of scale and scope, and increases market power (Montgomery \& Singh, 1984). Small firms often have difficulties in obtaining and securing critical resources whereas larger firms stand to benefit also from the perception of investors (Peng \& Heath, 1996). Firm size profitability relationship has produced contrasting results (Dalton \& Penn, 1976); while firm size is demonstrated as an important driver of firm performance (Peng \& Heath, 1996), others show that smaller firms are more profitable (Singh et al., 2007). Firm size is relevant when diversification is studied as firms pursue scale and scope economies in stages (Chen \& Ho, 2000; Denis et al., 1997; Benito-Osorio, Colino, \& Zuniga-Vicente, 2015). Studies in emerging markets have shown that firm size has a direct positive impact (Kakani, 2000) as well as moderates the diversification of firm performance relationship (Benito-Osorio et al., 2015). Hence our null hypothesis follows:

$\mathbf{H}_{\mathbf{0 4}}$ : There will be no significant impact of firm size on firm performance.

$\mathbf{H}_{\mathbf{0 4 a}}$ : There will be no significant interaction effects between firm size and corporate diversification in explaining firm performance.

The institution-based view conceptualizes institutions as the rules of the game and as informal constraints (North, 1993; Chen \& Chu, 2012). Factoring home country environments and institutional settings in frameworks studying diversification firm performance relationship is important (Wan, 2005). Most diversification studies focus on task environments but ignore institutional setting as institutional framework is taken for granted (Peng, 2003). Even within emerging markets, diversification firm performance relationship varies between countries, with the level of institutional development (Chakrabarti et al., 2007; Ma et al., 2006). Korean studies show as institutions develop the performance of 
diversified groups deteriorate (Bae et al., 2008; Lee et al., 2008). Over the last three decades significant institutional reforms have been implemented in India in a phased manner, ranging from industrial deregulation, trade liberalization, tax and financial sector reforms and market deepening initiatives like liberalization of foreign direct investments (Mohan, 2007). Such reforms have been in the areas of liberalizing the industrial policy and licensing, foreign direct investments, capital market regulator oversight and governance, banking, aviation, direct and indirect taxation, labor and product markets. Hence our null hypothesis follows:

$\mathbf{H}_{05}$ : The impact of corporate diversification and its interaction effects with ownership structure industry structure and firm size, on firm performance will not vary for the three time periods.

The conceptual model is presented in Figure 1.

The study was conducted on the three distinct institutional settings; pre-liberalization phase, transition phase and post-liberalization phase. The hypotheses were tested separately for the three phases. The transition phase covered a recessionary phase while the others represented growth periods. The database provided by the Center for Monitoring the Indian Economy (CMIE) formed the basis for the data for this study which is comprehensive and reliable (Khanna \& Palepu, 2000; Kakani, 2001).

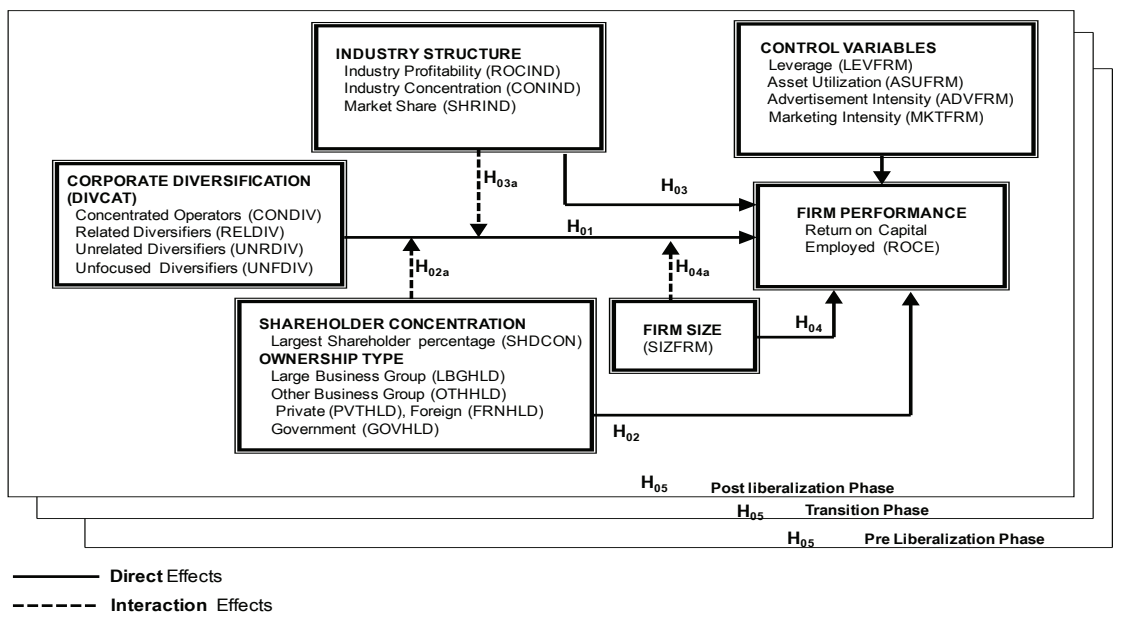

Figure 1: Conceptual Model 


\section{DATA AND METHODOLOGY}

The largest 200 firms, by sales, listed in the Bombay Stock Exchange for the three phases formed the initial sample frame. From this list, firms that were not present in all the phases were excluded. The final sample consisted of 228 firms, 229 firms and 242 firms in the three phases, respectively. The primary products of the final sample firms belonged to 157 'four digit' industry codes under the National Industrial Classification (NIC) scheme, 2004, with a well-balanced representation from a wide range of industries. The sample represented around $48 \%$ to $54 \%$ of all the companies listed on the Bombay Stock Exchange.

The concept of corporate diversity does not lend itself to easy conceptualization and measurement (Varadarajan \& Ramanujam, 1989). There has been a wide range of diversity measures that has been employed in the strategy literature. The literature shows that industrial organization researchers (Gort, 1962; Markham, 1973) used product count measures of firm diversity and were unable to establish a significant relationship between diversification and firm performance. Strategy researchers (Jaquemin \& Berry, 1979; Wrigley, 1970) having differentiated between related and unrelated components of diversification, Rumelt $(1974,1982)$ classified firms into seven categories based on the relatedness of their product portfolios. Although Rumelt's classification is marginally superior in terms of establishing the relatedness of the business of the firm, to the core skills the firm possesses, it is considered to be a laborious and subjective to measure, especially in cases of large sample analysis. Other measures of diversity with marginal variations of the existing measures were developed (Nayyar, 1992; Barnea \& Logue, 1972; Varadarajan \& Ramanujam, 1987, Amit \& Livnat, 1988), but the entropy measure (Jaquemin \& Berry, 1979) has demonstrated superiority in spite of being less subjective and it is highly correlated to Rumelt's categorical measures (Amit \& Livnat, 1988).

This large sample study used the entropy measure of diversification that was developed by Jaquemin and Berry (1979) and popularized by Palepu (1985) which provides three indices for each firm, the index of 'Related Diversification (DR)', the index of Unrelated Diversification (DU) and the index of Total diversification (DT), such that DT is the sum of DR and DU. Since the three measures of diversification, per say, do not capture the extent 
of diversification, and the direction of diversification (related or unrelated) under one single construct, this study created a categorical taxonomy of firm diversity. From the index of Related Diversification (DR) and Unrelated Diversification (DU), four diversification categories (DIVCAT) were created; Concentrated Operators (CONDIV), Related Diversifiers (RELDIV), Unfocussed Operators (UNFDIV) and Unrelated Diversifiers (UNRDIV) based on entropy measure of diversification (Jacquemin \& Berry, 1979, Palepu, 1985). Ownership Type (OWNCAT) were classified based on the CMIE database PROWESS ownership classification system. They were Large Business Group Shareholders (LBGHLD), Other Group Shareholders OTHHLD, Private Shareholders (PVTHLD), Foreign Shareholders (FRNHLD) and Government Shareholders (GOVHLD). Shareholder Concentration (SHDCON) was measured as the largest percentage of equity shares held by one single party, or a specific group (Amihud \& Lev, 1981; Thomsen \& Pedersen, 2000; Chen \& Ho, 2000). Industry structure variables (Kwoka, 1981) included Industry Profitability (ROCIND) measured as weighted average of the profitability of the industries in which the firm was operating. Measured as $\sum_{j} m_{i j 4} R O C E_{j} /$ $\sum_{j} m_{i j 4}$; ROCE is the Return on Capital employed associated with the fourdigit industry $\mathrm{j}, \mathrm{m}_{\mathrm{ij} 4}$ is the percentage of Firm i's total sales that were in the four digit industry j. Industry Concentration (CONIND) was measured as Weighted Average Four Firm Concentration Ratio is Measured as: $\sum_{j} m$ ${ }_{i j 4} \mathrm{CON}_{j} / \sum_{j} m_{i j 4}$. CON is the Four Firm Concentration (being \% of Sales which the top four firms control in each of the four-digit industry $j$ ), $m_{\mathrm{ij} 4}$ was the percentage of Firm i's total sales that are in the four digit industry $j$. Market Share (SHRIND) was measured as Weighted Average Market share and is Measured as; $\sum_{j} m_{i j 4} S H R_{j} / \sum_{j} m_{i j 4}$. SHR was the Market Share of the firm each in the four-digit industry $\mathrm{j}, \mathrm{m}_{\mathrm{ij} 4}$ was the percentage of Firm i's total sales that were in the four digit industry j. Firm Size (SIZFRM) was measured as Log of Firm Net Sales (Ma et al., 2006). Leverage (LEVFRM) was measured as firm debt divided by firm debt plus equity (Singh et al., 2007). Asset Utilization (ASUFRM) was measured as a percentage of firm net sales to net fixed Assets (Pawaskar, 1999). Advertisement Intensity (ADVFRM) was measured as advertisement costs as a percentage of net sales. Marketing Intensity (MKTFRM) was measured as a percentage of firm marketing costs to net sales. A variety of measures were used in the diversification literature to measure performance. Under Accounting based methods, Return on Capital Employed (ROCFRM) captures the efficiency 
of both the debt and equity and has been widely employed by researchers (Rumelt, 1991).

Studies on diversification performance relationship have predominantly used regression analysis (Markides \& Williamson, 1994), moderated regression analysis (Jacquemin \& Berry, 1979), panel regression analysis ( $\mathrm{Li}$ \& Greenwood, 2004), t-tests, f-tests and analysis of variances (Montgomery, 1981; Palepu, 1985). It was proposed to use general linear univariate model (GLM model) to uncover the main and interaction effects of categorical independent variables on an interval dependent variable. While regression models cannot handle interaction unless explicit cross-product interaction terms are added, the GLM model uncovers interaction effects on a built-in basis.

A GLM univariate model helps to assess whether there are significant group differences on a single continuous dependent variable, after controlling for the effect of one or more continuous independent variables called covariates (Harlow, 2001). The model allows for categorical as well as continuous independent variables and a continuous dependent variable. The model can be viewed as a combination of ANOVA and multiple regression as in both the cases the focus is on separating groups as well as correlating variables. The GLM univariate model is similar to ANOVA as both examine group differences with the same kinds of independent and dependent variables. However, the GLM univariate model has greater capability to fine tune the nature of the group differences by including other possible confounding independent variables and covariates which help to assess how much the groups differ on a dependent variable that is separate from any relationship with other confounding variables thereby providing a clear picture of group differences than when using ANOVA, which does not allow for inclusion of covariates (Harlow, 2001). Partial eta squared (PES) is the measure of effect size. It measures the proportion of the total variance in a dependent variable that is associated with the membership of different groups defined by an independent variable, in which the effects of other independent variables and interactions are partialled out.

The GLM Univariate methodology was chosen over other methodologies, especially given the fact that the independent variables in this study were categorical (diversification and ownership type) and the 
dependent variable (firm performance) was continuous in nature. More importantly, the dependent variable needed to be controlled for a host of independent variables that were continuous in nature; the GLM Univariate methodology is most suited for a situation like this (Harlow, 2001).

\section{RESULTS}

The GLM univariate model requires the covariates to be moderately correlated with the dependent variable making it worthwhile to use up an extra degree of freedom for each covariate that is included. Further if the correlation between the covariate and the dependent variable is too small very little variance will be partialled out of the dependent variable before examining the group differences. The model also requires the covariates to be reliably measured and there should be low correlations among covariates. Table 1 provides descriptive statistics and Pearson correlations for the variables, for each of the phases.

Table 1: Descriptive Statistics and Pearson Correlations

Table 1(a): Descriptive Statistics and Pearson Correlations: Post-liberalization phase

\begin{tabular}{|c|c|c|c|c|c|c|c|c|c|c|c|c|c|c|}
\hline & Mean & Std.Dev & 1 & 2 & 3 & 4 & 5 & 6 & 7 & 8 & 9 & 10 & 11 & 12 \\
\hline \begin{tabular}{|l|l|} 
1 & ROCFRM \\
\end{tabular} & 24.75 & 17.01 & 1.000 & & & & & & & & & & & \\
\hline \begin{tabular}{l|l}
2 & DIVCAT \\
\end{tabular} & 2.37 & 1.13 & $141^{* \star}$ & 1.000 & & & & & & & & & & \\
\hline \begin{tabular}{|l|l|}
3 & OWNCAT \\
\end{tabular} & 2.24 & 1.44 & $.152^{* *}$ & $-184^{* \star}$ & 1.000 & & & & & & & & & \\
\hline \begin{tabular}{l|l|l|l|l}
4 & LEVRM \\
\end{tabular} & 0.33 & 0.39 & $-259^{* \star *}$ & 0.023 & $-153^{* \star}$ & 1.000 & & & & & & & & \\
\hline \begin{tabular}{|l|l|}
5 & ASUFRM \\
\end{tabular} & 4.47 & 5.11 & $.238^{* * *}$ & -0.031 & $0.121^{*}$ & $-.169^{* \star}$ & 1.000 & & & & & & & \\
\hline \begin{tabular}{|l|l|}
6 & ADVFRM \\
\end{tabular} & 1.03 & 2.51 & $.245^{* \star \star}$ & $\mid-0.022$ & 0.025 & $-.155^{\star \star}$ & 0.096 & 1.000 & & & & & & \\
\hline \begin{tabular}{|l|l|}
7 & MKTFRM \\
\end{tabular} & 2.17 & 2.82 & $-186^{\star \star}$ & 0.056 & -0.020 & \begin{tabular}{|l|}
-0.034 \\
\end{tabular} & \begin{tabular}{|l|}
-0.108 \\
\end{tabular} & 0.031 & 1.000 & & & & & \\
\hline \begin{tabular}{|l|l|}
8 & ROCIND \\
\end{tabular} & 26.77 & 14.78 & $.454^{* \star *}$ & -0.074 & $.211^{* *}$ & $-199^{* *}$ & 0.044 & $0.127^{\star}$ & \begin{tabular}{|c|}
-0.018 \\
\end{tabular} & 1.000 & & & & \\
\hline \begin{tabular}{l|l|l|l|l|l|}
9 & CONIN \\
\end{tabular} & 55.74 & 22.12 & $208^{* \star}$ & $-0.11^{*}$ & $.130^{* *}$ & -0.065 & $.144^{* \star}$ & $.172^{\star \star}$ & 0.006 & $.239^{* \star * t}$ & 1.000 & & & \\
\hline 10 SHRIND & 12.34 & 15.71 & $.299^{* \star \star}$ & \begin{tabular}{|l|}
-0.090 \\
\end{tabular} & $.159^{* *}$ & $-.186^{* *}$ & 0.089 & 0.079 & -0.056 & $.135^{\star \star}$ & $.553^{\star \star \star}$ & 1.000 & & \\
\hline 11 SIZFRM & 7.06 & 1.37 & $.369^{* * *}$ & \begin{tabular}{|c|}
$-142^{\star *}$ \\
\end{tabular} & $.169^{* *}$ & $-.148^{* \star}$ & 0.044 & 0.000 & $-0.124^{*}$ & $.148^{* *}$ & $.239^{* \star \star}$ & $.377^{\star \star \star *}$ & 1.000 & \\
\hline \begin{tabular}{l|l|}
12 & SHDCON \\
\end{tabular} & 50.20 & 19.18 & $.165^{*}$ & $-.131^{\star \star}$ & $.384^{4 * \star}$ & -0.095 & 0.099 & -0.045 & 0.081 & $.175^{* *}$ & 0.063 & \begin{tabular}{|l|l|}
0.014 \\
\end{tabular} & 0.063 & 1.000 \\
\hline
\end{tabular}


Table 1(b): Descriptive Statistics and Pearson Correlations:

Transition phase

\begin{tabular}{|c|c|c|c|c|c|c|c|c|c|c|c|c|c|c|}
\hline & Mean & Std.Dev & 1 & 2 & 3 & 4 & 5 & 6 & 7 & 8 & 9 & 10 & 11 & 12 \\
\hline \begin{tabular}{l|l|}
1 & ROCFRM \\
\end{tabular} & 21.83 & 18.03 & 1.000 & & & & & & & & & & & \\
\hline \begin{tabular}{l|l}
2 & DIVCAT \\
\end{tabular} & 2.47 & 1.12 & $-154^{* *}$ & 1.000 & & & & & & & & & & \\
\hline 3 OWNCAT & 2.32 & 1.51 & 0.043 & $-.193^{* *}$ & 1.000 & & & & & & & & & \\
\hline 4 LEVFRM & 0.33 & 0.99 & 0.042 & $0.117^{\star}$ & -0.050 & 1.000 & & & & & & & & \\
\hline \begin{tabular}{l|l|}
5 & ASUFRM \\
\end{tabular} & 3.69 & 4.85 & $.199^{\star *}$ & -0.089 & $0.125^{*}$ & -0.064 & 1.000 & & & & & & & \\
\hline \begin{tabular}{c|l|}
6 & ADVFRM \\
\end{tabular} & 1.15 & 2.77 & $.222^{\text {*** }}$ & -0.087 & -0.016 & -0.035 & $159^{\star \star}$ & 1.000 & & & & & & \\
\hline \begin{tabular}{l|l|}
7 & MKTFRM \\
\end{tabular} & 2.40 & 3.23 & -0.083 & 0.052 & -0.035 & -0.046 & -0.069 & 0.034 & 1.000 & & & & & \\
\hline \begin{tabular}{l|l}
$80 C I N D$ \\
\end{tabular} & 22.15 & 9.02 & $297^{\star \star \star}$ & -0.097 & $.146^{\star \star}$ & -0.107 & $.212^{\star \star}$ & $.482^{\star \star \star}$ & -0.044 & 1.000 & & & & \\
\hline \begin{tabular}{l|l}
9 & CONIND \\
\end{tabular} & 55.87 & 20.93 & 0.017 & -0.106 & $0.123^{*}$ & -0.009 & 0.012 & $221^{* \star}$ & -0.056 & $173^{* \star}$ & 1.000 & & & \\
\hline \begin{tabular}{l|l}
10 & SHRIND \\
\end{tabular} & 12.69 & 16.81 & $.171^{\star *}$ & \begin{tabular}{|l|}
-0.035 \\
\end{tabular} & $162^{\star \star}$ & 0.003 & 0.032 & 0.068 & -0.057 & 0.039 & $.532^{* \star \star}$ & 1.000 & & \\
\hline \begin{tabular}{|l|l|}
11 & SIZFRM \\
\end{tabular} & 6.67 & 1.24 & $.263^{\star \star \star}$ & $-0.128^{*}$ & $.163^{\star \star}$ & -0.011 & 0.028 & 0.045 & $-.171^{\star \star}$ & $131^{* \star}$ & $203^{* \star}$ & $314^{\star \star \star}$ & 1.000 & \\
\hline 12 SHDCON & 49.25 & 20.27 & 0.018 & $-0.11^{*}$ & $.521^{\star \star \star}$ & 0.067 & 0.074 & 0.003 & 0.055 & $.137^{\star \star}$ & $0.119^{*}$ & 0.058 & 0.009 & 1.000 \\
\hline
\end{tabular}

Table 1(c): Descriptive Statistics and Pearson

Correlations: Pre-liberalization phase

\begin{tabular}{|c|c|c|c|c|c|c|c|c|c|c|c|c|c|c|c|}
\hline & & Mean & Std.Dev & 1 & 2 & 3 & 4 & 5 & 6 & 7 & 8 & 9 & 10 & 11 & 12 \\
\hline & ROCFRM & 37.29 & 20.85 & 1.000 & & & & & & & & & & & \\
\hline & DIVCAT & 2.36 & 1.11 & $0.108^{*}$ & 1.000 & & & & & & & & & & -- \\
\hline 3 & OWNCAT & 2.29 & 1.48 & $-0.116^{*}$ & $-.131^{* *}$ & 1.000 & & & & & & & & & - \\
\hline 4 & LEVFRM & 0.48 & 0.27 & $-307^{\star \star \star *}$ & 0.050 & $-202^{\star *}$ & 1.000 & & & & & & & & -- \\
\hline 5 & ASUFRM & 4.25 & 4.97 & $.416^{* \star *}$ & 0.032 & 0.013 & $-.170^{\star \star}$ & 1.000 & & & & & & & - \\
\hline 6 & ADVFRM & 0.68 & 1.32 & $480^{* \star \star}$ & 0.079 & -0.043 & $-.162^{\star \star}$ & $.193^{* *}$ & 1.000 & & & & & & -- \\
\hline 7 & MKTFRM & 1.84 & 3.32 & -0.016 & -0.021 & $0.121^{\star}$ & -0.032 & 0.029 & -0.029 & 1.000 & & & & & - \\
\hline & ROCIND & 35.50 & 14.28 & $458^{\star \star \star}$ & $.161^{* \star}$ & -0.030 & $-.268^{\star \star \star \star}$ & $.298^{\star \star \star}$ & $.489^{* \star *}$ & 0.057 & 1.000 & & & & - \\
\hline 9 & CONIND & 63.27 & 22.54 & $.158^{* *}$ & $-.143^{* *}$ & $.164^{\star \star}$ & $-.153^{\star \star}$ & $.209^{* *}$ & $.200^{* *}$ & -0.018 & $.228^{\star * \star}$ & 1.000 & & & -- \\
\hline 10 & SHRIND & 13.00 & 15.65 & 0.075 & 0.020 & $.236^{\star \star \star}$ & $-0.12^{*}$ & $.160^{* *}$ & 0.092 & -0.030 & $.147^{\star *}$ & $.525^{\star \star \star}$ & 1.000 & & - \\
\hline 11 & SIZFRM & 5.41 & 1.32 & -0.028 & $.163^{* \star}$ & $.141^{* *}$ & -0.012 & -0.042 & 0.017 & $.184^{* *}$ & $-0.107^{*}$ & 0.069 & $.363^{* * \star}$ & 1.000 & - \\
\hline 12 & SHDCON & -- & -- & -- & - & -- & - & - & - & -- & -- & - & -- & - & -- \\
\hline
\end{tabular}

*** Correlation is Significant at .01 level, ${ }^{* *}$ Correlation is Significant at .05 level, ${ }^{*}$ Correlation is Significant at .10 level. '- Shareholder concentration (SHDCON) data not available for the Pre-liberalization phase; hence not included

Table 2 provides analysis of variance (ANOVA) results by diversification categories and Table 3 provides ANOVA results by ownership type

Table 2: ANOVA Results; Diversification Categories

\begin{tabular}{lccccccccc}
\hline \multicolumn{3}{c}{ by Diversification categories } & \multicolumn{3}{c}{$\begin{array}{c}\text { ROCE for HIGH \& LOW } \\
\text { For Variables }\end{array}$} \\
\hline Variables & CONDIV & RELDIV & UNFDIV & UNRDIV & F Stat & HIGH & LOW & F Stat \\
\hline Post-Liberalization Phase & & & & & & \\
SHDCON & $52.66 \%$ & $52.29 \%$ & $49.15 \%$ & $45.76 \%$ & 1.428 & $27.80 \%$ & $21.71 \%$ & $7.518^{* *}$ \\
SIZFRM & 7.34 & 6.91 & 7.08 & 6.73 & $2.161^{*}$ & $28.68 \%$ & $20.69 \%$ & $13.249^{* * *}$ \\
LEVFRM & 0.31 & 0.36 & 0.33 & 0.34 & 0.182 & $22.78 \%$ & $26.76 \%$ & $3.147^{*}$ \\
ASUFRM & 5.00 & 3.43 & 4.65 & 4.31 & 0.885 & $28.74 \%$ & $20.77 \%$ & $13.182^{* * *}$ \\
ADVFRM & $1.18 \%$ & $0.92 \%$ & $0.88 \%$ & $1.12 \%$ & 0.213 & $25.44 \%$ & $24.07 \%$ & 0.369 \\
MKTFRM & $1.69 \%$ & $2.93 \%$ & $2.20 \%$ & $2.21 \%$ & 1.739 & $20.67 \%$ & $28.77 \%$ & $13.653^{* * *}$ \\
ROCIND & $25.42 \%$ & $34.66 \%$ & $25.53 \%$ & $23.44 \%$ & $5.391^{* *}$ & $30.25 \%$ & $14.35 \%$ & $25.984^{* * *}$ \\
CONIND & $61.44 \%$ & $50.41 \%$ & $53.11 \%$ & $55.47 \%$ & $2.826^{* *}$ & $27.96 \%$ & $21.49 \%$ & $8.510^{* *}$ \\
SHRIND & $15.82 \%$ & $8.19 \%$ & $11.53 \%$ & $11.77 \%$ & $2.288^{*}$ & $26.88 \%$ & $22.66 \%$ & $3.554^{*}$ \\
ROCFRM & $28.81 \%$ & $22.84 \%$ & $23.10 \%$ & $22.44 \%$ & 2.078 & - & - & - \\
\hline
\end{tabular}




\begin{tabular}{|c|c|c|c|c|c|c|c|c|}
\hline \multicolumn{6}{|c|}{$\begin{array}{c}\text { Mean of Variables } \\
\text { by Diversification categories }\end{array}$} & \multicolumn{3}{|c|}{$\begin{array}{l}\text { ROCE for HIGH \& LOW } \\
\text { For Variables }\end{array}$} \\
\hline \multirow[t]{2}{*}{ Variables } & & & & & & & & \\
\hline & CONDIV & RELDIV & UNFDIV & UNRDIV & F Stat & $\mathrm{HIGH}$ & LOW & F Stat \\
\hline \multicolumn{9}{|c|}{ Transition Phase } \\
\hline SHDCON & $50.85 \%$ & $53.33 \%$ & $47.09 \%$ & $45.98 \%$ & 1.536 & $23.89 \%$ & $19.74 \%$ & $3.056^{*}$ \\
\hline SIZFRM & 6.98 & 6.54 & 6.60 & 6.51 & 1.869 & $24.23 \%$ & $19.41 \%$ & $4.144^{* *}$ \\
\hline LEVFRM & 0.07 & 0.44 & 0.44 & 0.39 & 2.023 & $18.67 \%$ & $25.07 \%$ & $7.426^{* *}$ \\
\hline ASUFRM & 4.87 & 3.09 & 2.99 & 3.71 & 1.911 & $27.32 \%$ & $16.29 \%$ & $23.533^{\star * *}$ \\
\hline ADVFRM & $1.57 \%$ & $1.20 \%$ & $0.79 \%$ & $1.02 \%$ & 0.847 & $25.38 \%$ & $18.65 \%$ & $8.203^{\star *}$ \\
\hline MKTFRM & $1.51 \%$ & $3.21 \%$ & $2.93 \%$ & $1.99 \%$ & $3.635^{* *}$ & $19.65 \%$ & $24.02 \%$ & $3.403^{*}$ \\
\hline ROCIND & $23.70 \%$ & $22.60 \%$ & $20.34 \%$ & $21.97 \%$ & 1.474 & $26.75 \%$ & $16.86 \%$ & $18.538^{* * *}$ \\
\hline CONIND & $61.35 \%$ & $53.62 \%$ & $52.63 \%$ & $55.52 \%$ & $2.115^{\star}$ & $22.50 \%$ & $21.10 \%$ & 0.335 \\
\hline SHRIND & $14.84 \%$ & $10.95 \%$ & $11.77 \%$ & $13.04 \%$ & 0.589 & $25.04 \%$ & $20.39 \%$ & $3.290^{*}$ \\
\hline ROCFRM & $27.19 \%$ & $21.93 \%$ & $17.13 \%$ & $20.89 \%$ & $3.302^{* *}$ & - & - & - \\
\hline \multicolumn{9}{|c|}{ Pre-Liberalization Phase } \\
\hline SIZFRM & 5.088 & 5.361 & 5.667 & 5.552 & $2.772^{\star \star}$ & $35.61 \%$ & $38.99 \%$ & 1.597 \\
\hline LEVFRM & 0.46 & 0.45 & 0.51 & 0.48 & 0.662 & $32.30 \%$ & $42.44 \%$ & $15.148^{* * *}$ \\
\hline ASUFRM & 3.86 & 4.68 & 4.39 & 4.26 & 0.280 & $47.24 \%$ & $27.33 \%$ & $71.279^{* * *}$ \\
\hline ADVFRM & $0.55 \%$ & $0.74 \%$ & $0.66 \%$ & $0.92 \%$ & 0.728 & $42.56 \%$ & $31.93 \%$ & $16.755^{\star \star *}$ \\
\hline MKTFRM & $1.75 \%$ & $2.21 \%$ & $1.93 \%$ & $1.43 \%$ & 0.445 & $38.00 \%$ & $36.40 \%$ & 0.340 \\
\hline ROCIND & $33.58 \%$ & $32.55 \%$ & $36.55 \%$ & $39.96 \%$ & $2.658^{* *}$ & $44.35 \%$ & $30.11 \%$ & $31.840^{* * *}$ \\
\hline CONIND & $68.52 \%$ & $59.09 \%$ & $63.06 \%$ & 58.20 & $2.673^{* *}$ & $38.54 \%$ & $36.04 \%$ & 0.869 \\
\hline SHRIND & $12.58 \%$ & $13.12 \%$ & $13.07 \%$ & $13.50 \%$ & 0.034 & $39.30 \%$ & $32.57 \%$ & 2.280 \\
\hline ROCFRM & $35.21 \%$ & $35.56 \%$ & $36.67 \%$ & $42.03 \%$ & 1.108 & - & - & - \\
\hline
\end{tabular}

${ }^{* *}$ Sig. at .01 level, ${ }^{* *}$ Sig. at .05 level, ${ }^{*}$ Sig. at .10 level 


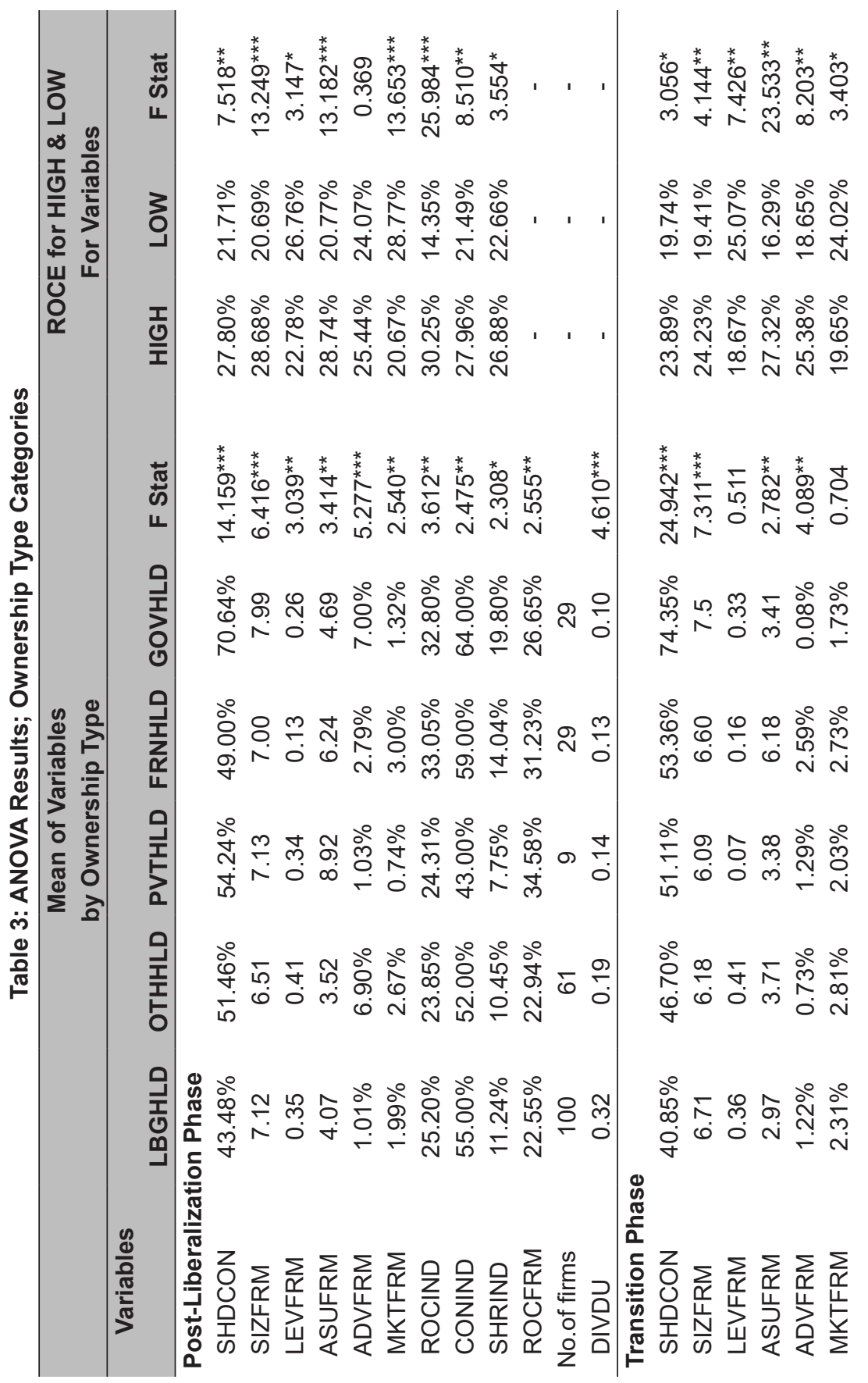




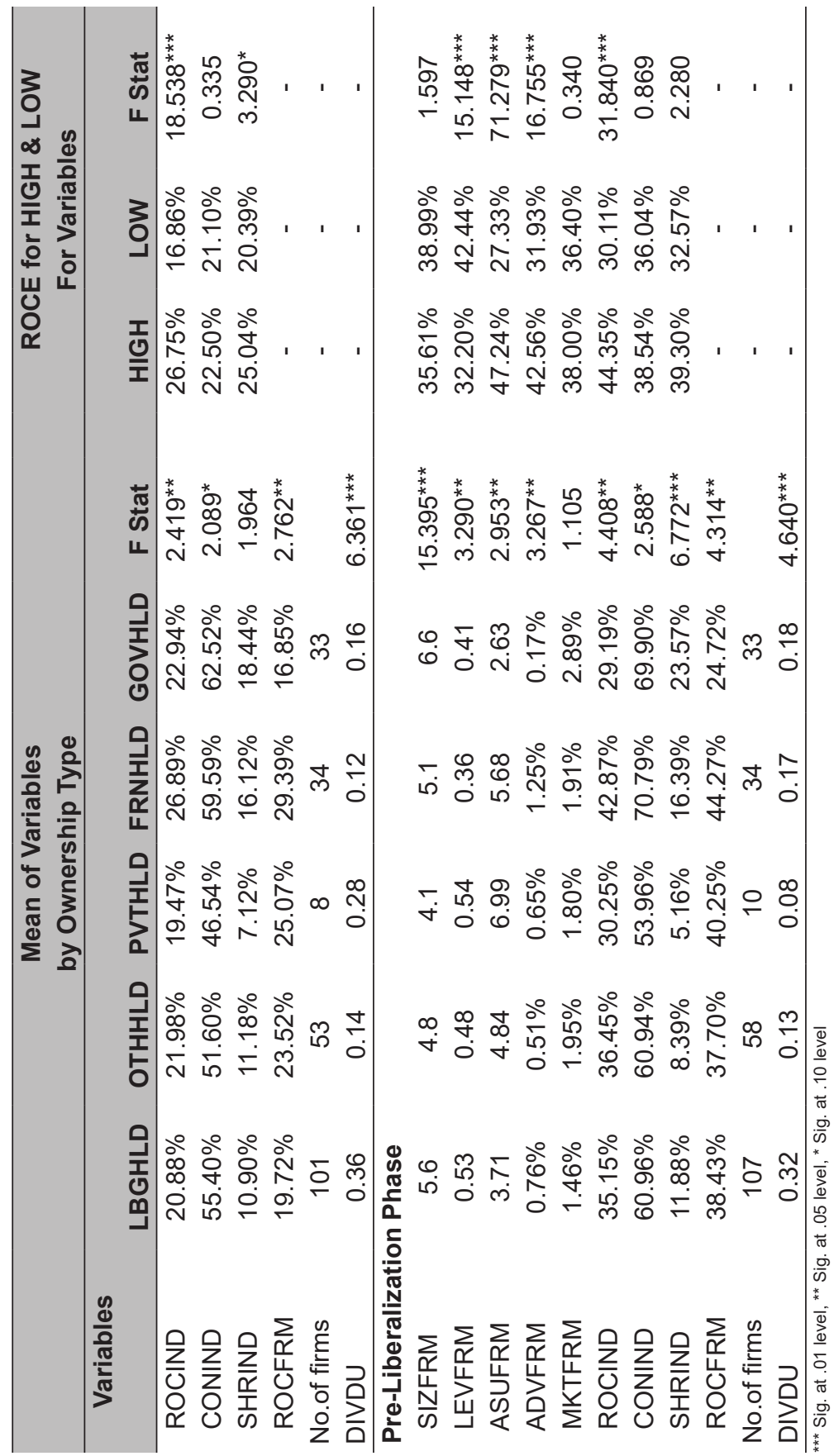


Table 4 provides the GLM model results. The GLM model produces 'estimated marginal means' (EMM) of the 'ANOVA Means' after controlling for the covariates. Plotting both the Means (from ANOVA, without effects of any covariates) and EMM (being ANOVA means adjusted for the covariates) provides a visual reference of the impact of the independent variable on the dependent variable after controlling for the covariates.

Table 4: Effect of Diversification, Ownership Structure, Industry Structure and Firm Size on Firm Performance; GLM Univariate Model Results

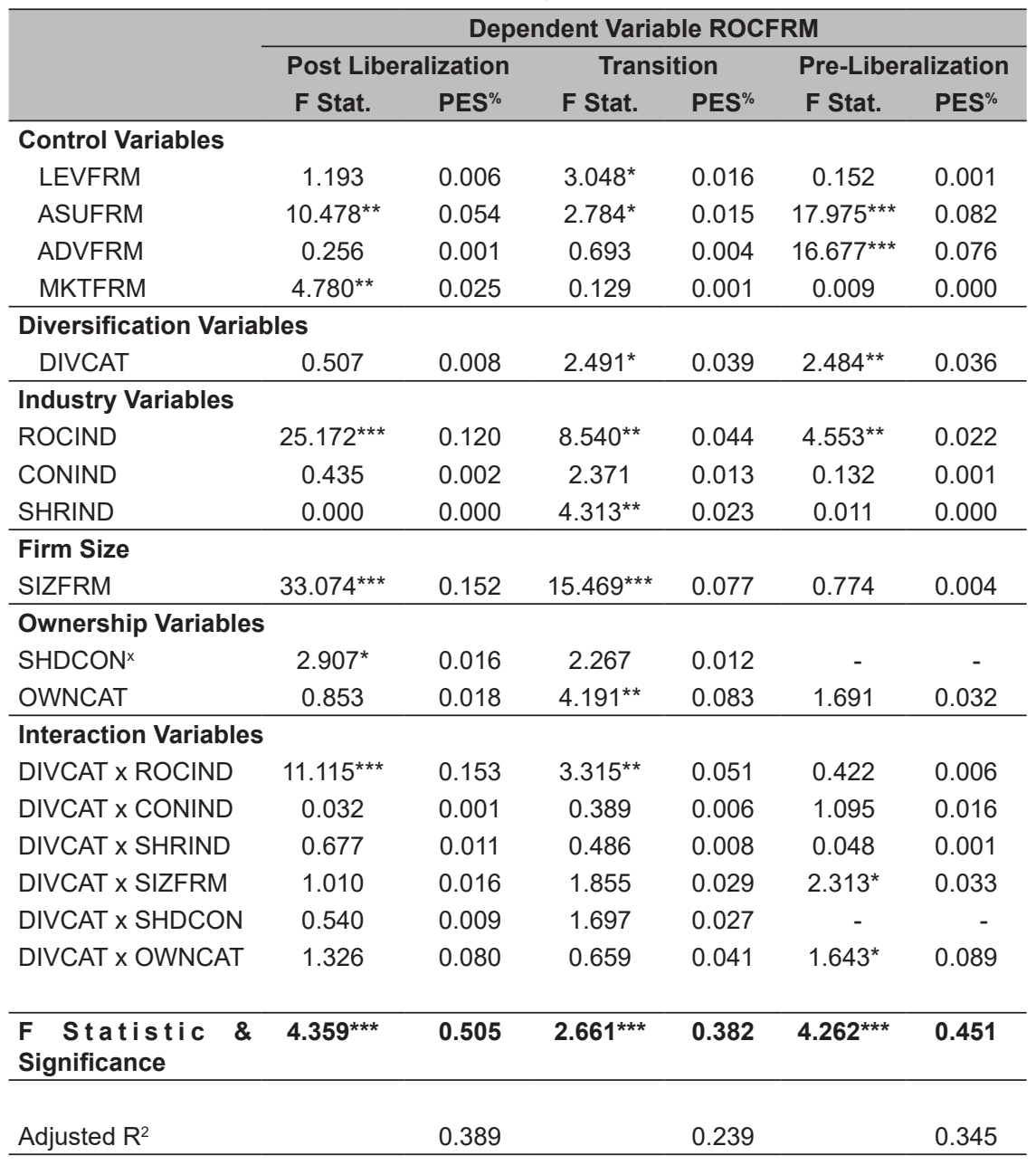


Figure 2 plots the GLM model graphs showing the means and estimated marginal means (EMM) for the four diversification categories, in each phase. Figure 3 plots the interaction effect of diversification categories and industry profitability for the post-liberalization phase.

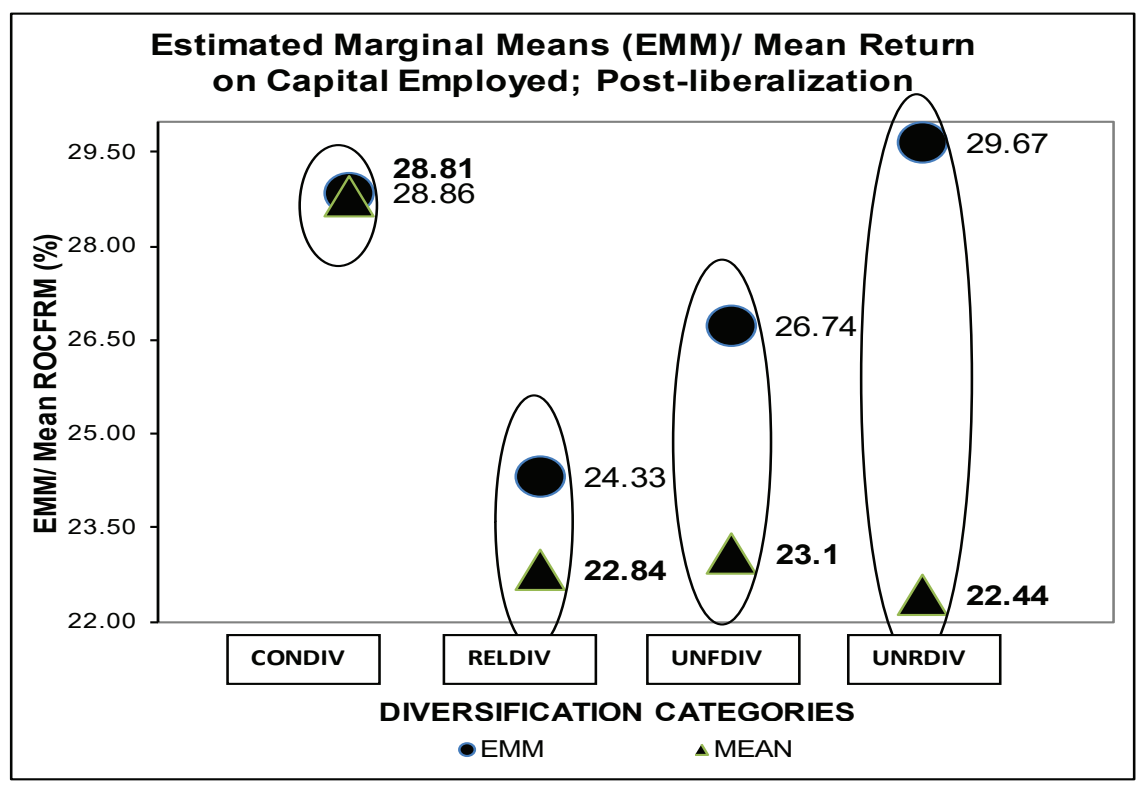

Figure 2: Firm performance by diversification categories Figure 2a: Post Liberalization Phase

$\mathrm{H}_{01}$ was rejected for the pre-liberalization and transition phases (Table 4) signifying that diversification explained firm performance for the preliberalization and transition phases, but it did not explain firm performance for the post liberalization phase (Table 4). Focused firms were least profitable during the pre-liberalization phase (35.21\%), but became most profitable in the transition $(27.19 \%)$ and post liberalization phase (28.81\%); although such difference was significant only during the transition phase (Table 2).

$\mathrm{H}_{02}$ with respect to ownership type (OWNCAT) was rejected only for the transition phase signifying that ownership type explains firm performance only during the transition phase (Table 4). Firms affiliated to large business groups were most diversified across all the three phases, least profitable during the transition and post liberalization phase $(19.72 \%$ and $22.55 \%$ respectively) but their profitability was not the lowest during 
the pre-liberalization phase $(38.43 \%)$, as seen in Table 3. Firms affiliated to large business groups had the lowest asset utilization across all the three phases (Table 3). They were present in industries with lowest industry profitability $(25.2 \%)$ and low industry concentration (55.0\%) during the post liberalization phase as compared to having been in highly profitable industries (35.15\%) and in industries with high concentration $(60.96 \%)$ during the pre-liberalization phase. $\mathrm{H}_{02}$ with respect to shareholder concentration was rejected for the post liberalization phase signifying that shareholder concentration explains firm performance (Table 4). $\mathrm{H}_{02}$ with respect to interaction effects between ownership type and diversification in explaining firm performance was rejected for the pre liberalization phase (Table 4).

$\mathrm{H}_{03}$ was rejected for all three phases signifying that industry profitability explains firm performance; Table 4 also shows that market share impacts firm performance for the transition phase. Focused firms are better positioned in terms of industry profitability, industry concentration and market share as compared to other firms in the post liberalization phase (Table 2). $\mathrm{H}_{03 \mathrm{a}}$ with respect to interaction effects between industry profitability and diversification in explaining firm performance was rejected for the transition and post liberalization phase (Table 4; Figure 3)

$\mathrm{H}_{04}$ was rejected for the transition and post liberalization phase signifying that firm size explains firm performance (Table 4) for these two phases. As seen in Table 2 focused firms have the largest size in the post liberalization phase (7.34) while they were the smallest in the pre liberalization phase (5.08). $\mathrm{H}_{04 \mathrm{a}}$ with respect to interaction of firm size with diversification in explaining firm performance was rejected only for the pre liberalization phase (Table 4).

$\mathrm{H}_{05}$ was rejected signifying that the impact of corporate diversification, and its interaction effects with ownership structure, industry structure and firm size, on firm performance varied for the three phases (Table 4). 


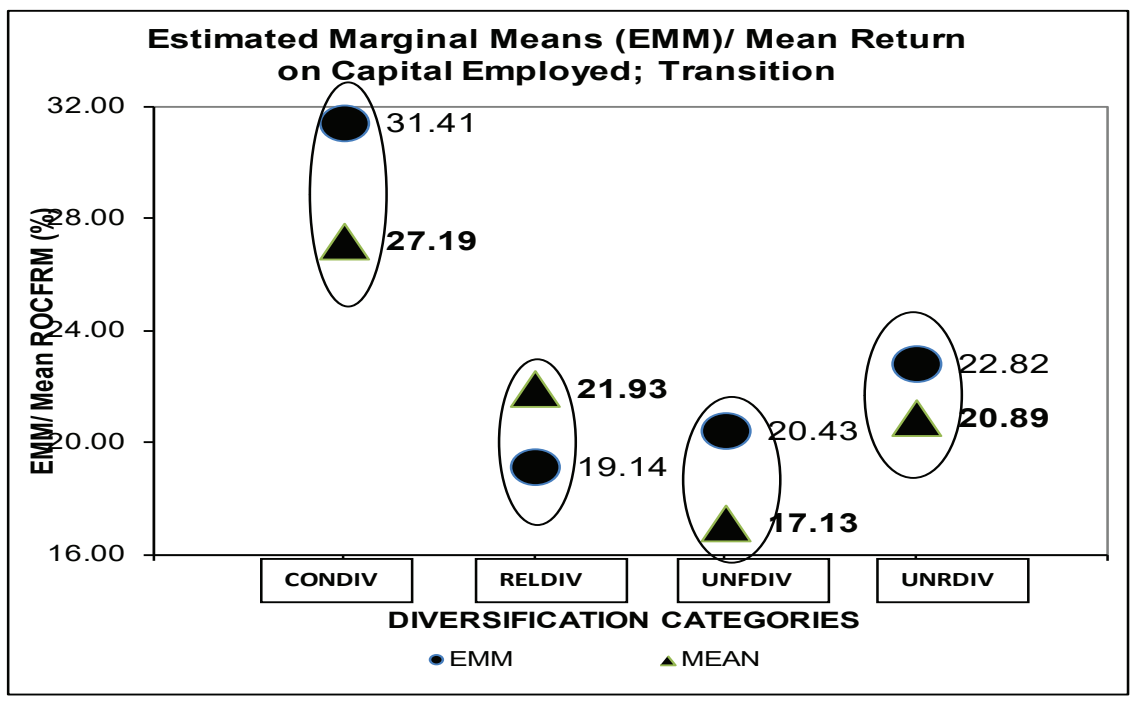

Figure 2b: Transition Phase

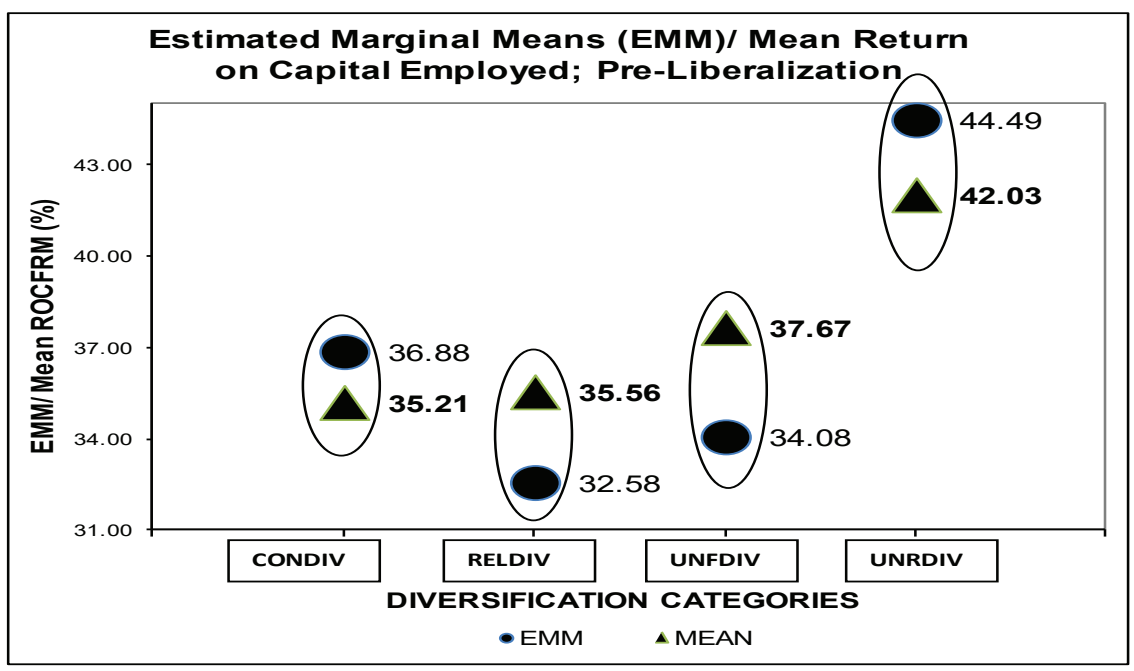

Figure 2c: Pre Liberalization Phase 


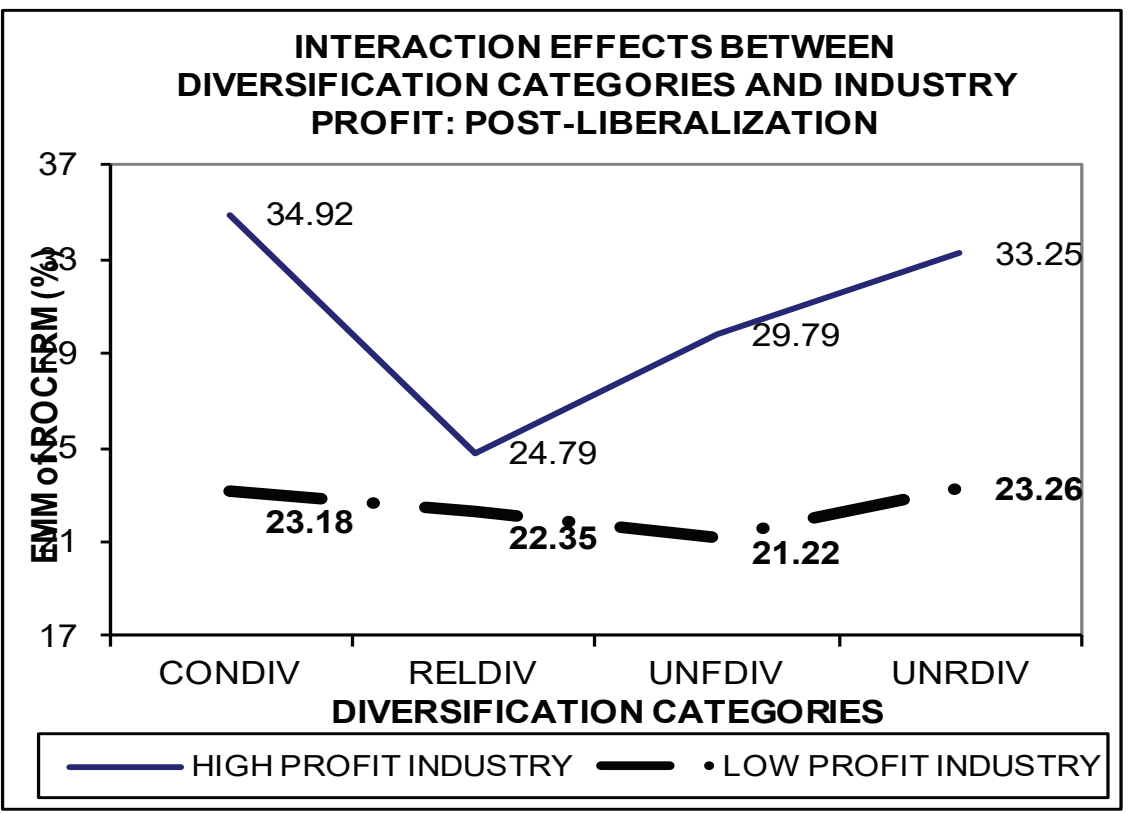

Figure 3: Diversification-Industry Profitability Interaction Effects:

Post Liberalization Phase

\section{CONCLUSIONS}

\section{Diversification Firm Performance Relationship}

Primarily, our study showed that diversification firm performance relationship varies as institutions develop within the same national context. This is in line with earlier studies of Chen and Chu (2012) and Wan (2005), but different from Kakani (2002). During the pre-liberalization phase, unrelated diversification was most profitable strategy and concentrated operations were the least profitable (Figure 2c); diversification also significantly explained firm performance. This is in line with the studies of Chen and Ho (2000), Yigit and Behram (2013), Wan (2005), Chakrabarti et al. (2007) and Ramaswamy et al. (2002). The position reversed during the transition phase as concentrated operation became most profitable while unrelated diversifiers achieved lower performance (Figure 2b). This is in line with prior research (Varadarajan \& Ramanujam, 1987; Wan, 2005; George, 2006; Lee at al., 2008; Baek et al., 2018). How can we interpret this 
reversal in diversification firm performance relationship between the two periods? Can the reversal be attributed to the Institutional Theory (North, 1993; Chen \& Chu, 2012) where the benefits of unrelated diversification wane away as institutions develop and become stronger? If that was the case, we expect to see unrelated diversifiers achieve inferior performance even during the post-liberalization phase as well, where institutions have further developed. Post-liberalization, there was neither a significant difference in firm performance between diversification categories nor did diversification significantly explain firm performance. We concluded that the variation in diversification firm performance relationship is not entirely attributable to institutional development. Since the transition phase was recessionary, we interpreted that unrelated diversification turning inferior and concentrated operators demonstrating positive performance during the transition phase was due to recessionary conditions. This is in line with Gopalan and Xie (2011) and Chakrabarti et al. (2007) who showed that even in least developed institutional contexts; unrelated diversification offers limited benefits when economy-wide shocks strike. Although there was no difference in firm performance between diversification categories post-liberalization, we concluded that concentrated operators were able to scale to a larger size, were present in most profitable industries as well as make the most productive use of their assets, resulting in their superior performance. Unrelated diversifiers lose out on these counts.

We further concluded that post-liberalization unrelated diversification is not yet a value-reducing phenomenon, as long as firms achieve adequate scale. However, keeping the unrelated business profitable during business cycle downswing conditions could be challenging; the point which this study brings out clearly. One reason for diversification not having significantly impacted firm performance during the post-liberalization phase could be that, such unrelatedly diversified firms are still better positioned to manage their high level of diversity and still preserve their profitability by virtue of superior management depth (Campa \& Kedia, 2002; Prahalad \& Bettis, 1986) and effective organizational structure (Klein \& Saidenberg, 2010).

We analyzed a few sample companies to demonstrate our interpretations and conclusions with respect to diversification firm performance relationship. In the pre-liberalization phase unrelatedly diversified companies were larger than other companies and were performing well. Very large diversified 
players like ITC Ltd with interests in cigarettes, paper, hotels and fast moving consumer goods segments and Reliance Industries with diversified businesses across oil and gas and consumer business demonstrated superior performance. Highly diversified companies like Bajaj Electricals (diversified into lighting, appliances, fans, LPG based generators, engineering and projects) and Standard Industries owned by the Mafatlal group (textiles, chemicals, real estate) had superior profits in comparison to peers. Although companies focused into single business like Infosys Technologies and Dr Reddy's laboratories were also profitable, in totality focused players were less profitable as compared to diversified players. It is a fair interpretation that during the pre-liberalization phase, unrelated diversifiers used their scale and non-market based capabilities (Wan, 2005) in contexts of low institutional developments to gain competitive advantage.

The transition phase saw the financial performance of unrelated diversifiers being adversely impacted. Profitability of ITC almost halved and that of Reliance Industries dropped sharply. Bajaj Electricals lost almost two thirds in profitability and Standard Industries slipped into losses. On the contrary, profitability of focused players however remained more or less stable. Post-liberalization, although there was no significant difference in profitability between unrelatedly diversified and focused firms; highly diversified companies bounced back in comparison to the transition phase. For example, unrelatedly diversified companies like ITC, Reliance Industries, Bajaj Electricals and Standard Industries substantially improved in comparison to industry peers. Focused single business companies were able to scale to much larger size than the unrelated diversifiers; companies like Tata Consultancy Services, Maruti Udyog Limited and Indian Oil Corporation scaled steeply; they were also present in profitable industries and also had superior asset utilization, all of which translated into superior firm performance.

\section{Ownership Type in The Context of Diversification Firm Performance Relationship}

Firms affiliated to large business groups were more unrelatedly diversified as compared to others, across all three phases. This is in line with Khanna and Palepu $(1997,2000)$ and Ma et al. (2006). However, our results showed that firms affiliated to large business groups failed to capitalize 
on the low institutional development during the pre-liberalization phase to gain competitive advantage; they have failed to take advantage of their unrelated diversity and transform the same into superior firm performance, while firms owned by private and foreign shareholders performed superiorly. This finding is in line with studies of Singh et al. (2007), Kakani (2000) and Rajan et al. (2000) but different from the studies of Khanna and Palepu (1997, 2000) and Chen and Chu (2012). Further, the interaction effects between diversification and ownership types in explaining firm performance during the pre-liberalization phase showed that firms owned by different ownership types demonstrated contrasting performance outcomes while handling distinct types of diversification strategies. With rapid institutional development that followed during the fifteen year period (Mohan, 2007), firms affiliated to large business groups became the lowest performers, were present in low profit industries and had the lowest average market share as they missed the opportunity to reposition themselves, be it in terms of reducing the level of unrelated diversification or building appropriate firm level capabilities. This is an interesting research contribution. Shareholder concentration significantly impacting firm performance during the postliberalization phase also supports the view that irrespective of the ownership type, large block shareholding has started to play a crucial role in impacting firm performance. This is in line with Aguilra et al. (2015), Hoechle et al. (2012), Ramaswamy et al. (2002) and George (2007).

We considered few sample companies to demonstrate our interpretations and conclusions with respect to ownership type and its impact on diversification firm performance relationship. During the pre-liberalization phase firms owned by large business groups were the most unrelated companies as compared to others. For example, the K.K. Birla group owned Texmaco had businesses across sectors like engineering, procurement, construction (EPC), fabricating wagons, locomotives and steel castings. The Aditya Birla group owned Century Textiles and Industries was spread across diverse businesses like textiles, cement, chemicals and paper. Another Aditya Birla group owned company Aditya Birla Nuvo had diversified interests in financial services, fertilizers, rayon, textiles and telecom. The Tata Group company, Voltas had diversified interests across air conditioners, beverages, pesticides and chemicals. In spite of their size and institutional weakness in the economy which they could have taken advantage of (Lee et al., 2008; Chen \& Chu, 2012; Wan, 2005), large business group owned 
firms fell short in terms of profitability as compared to private and foreign owned companies.

During the transition and post liberalization phases, firms owned by large business groups failed to reduce their level of unrelated diversification. Aditya Birla Nuvo continued to be highly diversified while there was a steep drop in its profitability. Some of them had even increased their unrelated diversification posture; Century Textiles for example saw a sharp increase in its unrelated diversification with profitability dropping while Reliance Industries increased its diversification although it continued to preserve its profitability. Some of the large business group owned firms like Tata's owned Voltas did reduce its unrelated diversity by almost half but still saw a drop in its profitability. Overall, firms owned by large business groups neither took advantage of their unrelated diversity in periods of low institutional development nor did they reduce their unrelated diversity as institutions developed, scarifying their competitiveness in both situations.

\section{Managerial Implications}

There are many implications to practitioners. Firstly, given the institutional development in the Indian context, managers need to cautiously play when it comes to unrelated diversification decisions. Unrelated diversification is beneficial only when companies are able to scale, be present in profitable industries as well as make the most productive use of their assets, which is challenging. Only few large conglomerates that have idiosyncratic capabilities (Campa \& Kedia, 2002; Prahalad \& Bettis, 1986) to handle such diversity, like Reliance Industries that is continuing to invest in unrelated diversification across industries like oil and gas, retail and telecom and still remaining profitable (Reliance 2015). Secondly, managers need to realize that unrelated diversification can significantly erode value during business cycle downswing conditions; they need to build adequate sensitivities when proposing unrelated diversification investments (Gopalan $\&$ Xie, 2011). Thirdly, concentrated or focused, operations seems a superior strategy as focused firms are able to scale to a larger size, are able to be in high concentration industries as well as secure higher market shares. 


\section{LIMITATIONS AND SCOPE FOR FUTURE RESEARCH}

The study was done at a firm level but can also be replicated at a business group level as around $65 \%$ of the sample firms are affiliated to large business groups. The study can be extended to probe as to why related diversifiers have failed to create outstanding shareholder-value, in spite of substantial institutional development that has taken place over the three phases. This study assumed 'a priori' that institutions have developed over the fifteen years. There is a scope to come up with an institutional development 'index and cluster the fifteen years into distinct periods of low, medium and high institutional development and test our hypothesis. This possibly will provide a scope for future research. Additionally, this study could be extended to a small sample clinical research by identifying firms that have been successful, and those that have not been, in light of differing diversification strategies.

\section{REFERENCES}

Aguilera, R. V., Desender, K., Bednar, M. K., \& Lee, J. H. (2015). Connecting the dots: Bringing external corporate governance into the corporate governance puzzle. The Academy of Management Annals, 9(1), 483-573.

Alchian, A. A., \& Demsetz, H. (1972). Production, information costs, and economic organization. The American Economic Review, 62(5), 777795 .

Amihud, Y., \& Lev, B. (1981). Risk reduction as a managerial motive for conglomerate mergers. The Bell Journal of Economics, 12, 605-617.

Amit, R., \& Livanit, J. (1988). Diversification strategies, business cycles and economic performance. Strategic Management Journal, 9(2), 99-110.

Ammann, M., Hoechle, D., \& Schmid, M. (2012). Is there really no conglomerate discount?. Journal of Business Finance \& Accounting, 39(1-2), 264-288. 
Amrah, M. R., \& Obaid, M. M. (2019). Effective corporate governance mechanisms, ownership structure and financial reporting quality: Evidence from Oman. Asia-Pacific Management Accounting Journal, 14(3), 119-150.

Anand, B. N., \& Jayanthi, S. (2005). Strategies of unrelated diversification. Harvard Business School Background Note 705-480.

Bae, S. C., Kwon, T. H., \& Lee, J. W. (2008). Corporate diversification, relatedness, and firm value: Evidence from Korean firms. Asia-Pacific Journal of Financial Studies, 37(6), 1025-1064.

Baek, S., Lee, K. Y., Lee, J. W., \& Mohanty, S. (2018). Diversification in Korean banking business: Is non-interest income a financial saviour?. Journal of Emerging Market Finance, 17(3_supp1), S299-S326.

Barnea, A., \& Logue, D. E. (1972). Stock market based measures of corporate diversification. Corporate Diversification, 51-60.

Barney, J. (1991). Firm resources and sustained competitive advantage. Journal of Management, 17(1), 99-120.

Barney, J. (1992). Integrating organizational behaviour and strategy formulation research: A resource based view. Working Paper. Texas A\&M, College Station, TX.

Barney, J. B., \& Griffin, R. W. (1992). The management of organizations: Strategy, structure, behavior. Boston: Houghton Mifflin Company.

Basu, N. (2010). Trends in corporate diversification. Financial Markets and Portfolio Management, 24(1), 87-102.

Benito-Osorio, D., Ángel Guerras-Martín, L., \& Ángel Zuñiga-Vicente, J., (2012). Four decades of research on product diversification: A literature review. Management Decision, 50(2), 325-344.

Benito-Osorio, D., Colino, A., \& Zúñiga-Vicente, J. Á. (2015). The link between product diversification and performance among Spanish 
manufacturing firms: Analyzing the role of firm size. Canadian Journal of Administrative Sciences, 32(1), 58-72.

Bettis, R. A. (1981). Performance differences in related and unrelated diversified firms. Strategic Management Journal, 2(4), 379-393.

Campa, J. M., \& Kedia, S. (2002). Explaining the diversification discount. The Journal of Finance, 57(4), 1731-1762.

Chakrabarti, A., Singh, K., \& Mahmood, I. (2007). Diversification and performance: Evidence from East Asian firms. Strategic Management Journal, 28(2), 101-120.

Chen, C. N., \& Chu, W. (2012). Diversification, resource concentration, and business group performance: Evidence from Taiwan. Asia Pacific Journal of Management, 29(4), 1045-1061.

Chen, S. S., \& Ho, K. W. (2000). Corporate diversification, ownership structure, and firm value: The Singapore evidence. International Review of Financial Analysis, 9(3), 315-326.

Dalton, J. A., \& Penn, D. W. (1976). The concentration-profitability relationship: Is there a critical concentration ratio? Journal of Industrial Economics, 25(2), 133-142.

Denis, D. J., Denis, D. K., \& Sarin, A. (1997). Agency problems, equity ownership, and corporate diversification. The Journal of Finance, 52(1), 135-160.

Gedajlovic, E. R., \& Shaprio, D. M. (1988). Management and ownership effects: Evidence from five countries. Strategic Management Journal, 19(6), 533-553.

George, R. P. (2007). Diversification and firm performance: The moderating influence of ownership structure and business group-affiliation. South Asian Journal of Management, 14(3), 66-94.

Ghemawat, P. (2007). Regional strategies for global leadership. Harvard Business Review, 83(12), 98-109. 
Gopalan, R., \& Xie, K. (2011). Conglomerates and industry distress. The Review of Financial Studies, 24(11), 3642-3687.

Gort, M. (1962). Diversification and integration in American industry. Princeton, NJ: Princeton University Press.

Grant, R. M., \& Jammine, A. P. (1988). Performance difference between the Wrigley/ Rumelt strategic categories. Strategic Management Journal, 9(4), 333-346.

Harlow, H. L. (2001). The essence of multivariate thinking: Basic themes and methods. London: Lawrence Erlbaum \& Associates.

Hawawini, G., Subramanian, V., \& Verdin, P. (2003). Is performance driven by industry-or firm-specific factors? A new look at the evidence. Strategic Management Journal, 24(1), 1-16.

Hill, C. W., \& Snell, S. A. (1988). External control, corporate strategy, and firm performance in research-intensive industries. Strategic Management Journal, 9(6), 577-590.

Hoechle, D., Schmid, M., Walter, I., \& Yermack, D. (2012). How much of the diversification discount can be explained by poor corporate governance?. Journal of Financial Economics, 103(1), 41-60.

Hoskisson, R. E., \& Turk, T. A. (1990). Corporate restructuring: Governance and control limits of the internal capital market. Academy of Management Review, 15(3), 459-477.

Hope, O. K., \& Thomas, W. B. (2008). Managerial empire building and firm disclosure. Journal of Accounting Research, 46(3), 591-626.

Jacquemin, A. P., \& Berry, C. H. (1979). Entropy measure of diversification and corporate growth. The Journal of Industrial Economics, 27(4), 359-369.

Jensen, M. C. (1986). Agency costs of free cash flow, corporate finance, and takeovers. The American Economic Review, 76(2), 323-329. 
Khanna, T., \& Palepu, K. G. (1997). Why focused strategies may be wrong for emerging markets. Harvard Business Review, 75, 41-54.

Khanna, T., \& Palepu. K. (2000). Is group affiliation profitable in emerging markets? An analysis of diversified Indian business groups. The Journal of Finance, 55(2), 867-891.

Kakani, R. K. (2000). Financial performance and diversification strategy of Indian business groups (Unpublished doctoral dissertation, Indian Institute of Management, Calcutta). Retrieved from https://www. researchgate.net/profile/Ram_Kakani/publication/242573147 Financial_Performance_and_Diversification_Strategy_of_Indian_ Business_Groups/links/56ea606e08ae25ede8313099.pdf

Kakani, R. K. (2001). Explaining diversified business groups failure \& focused business groups success in India (Unpublished Manuscript, Working paper series 2001(7), XLRI Jamshedpur. Retrieved from https://papers.ssrn.com/sol3/papers.cfm?abstract_id=906455

Klein, P. G., \& Saidenberg, M. R. (2010). Organizational structure and the diversification discount: Evidence from commercial banking. The Journal of Industrial Economics, 58(1), 127-155.

Kwoka, J. E. (1981). Does the choice on concentration measure really matter?. The Journal of Industrial Economics, 29(4), 445-453.

Lecraw, D. J. (1984). Diversification strategy and performance. Journal of Industrial Economics, 33, 179-198.

Lee, K., Peng, M. W., \& Lee, K. (2008). From diversification premium to diversification discount during institutional transitions. Journal of World Business, 43(1), 47-65.

Li, M., \& Wong, Y. Y. (2003). Diversification and economic performance: An empirical assessment of Chinese firms. Asia Pacific Journal of Management, 20(2), 243-265. 
Li, S. X., \& Greenwood, R. (2004). The effect of within-industry diversification on firm performance: Synergy creation, multi-market contact and market structuration. Strategic Management Journal, 25(12), 1131-1153.

Ma, X., Yao, X., \& Xi, Y. (2006). Business group affiliation and firm performance in a transition economy: A focus on ownership voids. Asia Pacific Journal of Management, 23(4), 467-483.

Mackey, T. B., Barney, J. B., \& Dotson, J. P. (2017). Corporate diversification and the value of individual firms: A Bayesian approach. Strategic Management Journal, 38(2), 322-341.

Markham, J. W. (1973). Conglomerate enterprise and public policy. Boston, MA: Harvard Business School.

Markides, C. C., \& Williamson, P. J. (1994). Related diversification, core competences and corporate performance. Strategic Management Journal, 15(S2), 149-165.

Mayer, M. \& Whittington, R. (2003). Diversification in context: A crossnational and cross-temporal extension. Strategic Management Journal, 24(8), 773-781.

Mohan, R. (2007). Global Banking: Paradigm Shift. Paper presented by the Deputy Governor Reserve Bank of India at FICCI-IBA Conference, Mumbai, September 14, 2007.

Montgomery, C. A. (1981). Diversification, market structure, and firm Performance: An extension of Rumelt's model (Unpublished Manuscript Doctoral dissertation, Purdue University).

Montgomery, C. A., \& Singh, H. (1984). Diversification strategy and systematic risk. Strategic Management Journal, 5(2), 181-191.

Nayyar, P. R. (1992). On the measurement of corporate diversification strategy: Evidence from large US service firms. Strategic Management Journal, 13, 219-235. 
North, D. C. (1993). Institutions and credible commitment. Journal of Institutional and Theoretical Economics, 149(1), 11-23.

Palepu, K. (1985). Diversification strategy, profit performance and entropy measures. Strategic Management Journal, 6(2), 239-255.

Palich, L. E., Cardinal, L. B., \& Miller, C. C. (2000). Curvinilearity in the diversification - performance linkage: An examination of over three decades of research. Strategic Management Journal, 21(2), 155-174.

Pawaskar, V. (1999). Effect of product market diversification on firm performance: A study of the Indian corporate sector (Unpublished $\mathrm{PhD}$. Dissertation, Indira Gandhi Institute of Development Research, Mumbai).

Peng, M. W. (2003). Institutional transitions and strategic choices. Academy of Management Review, 28(2), 275-296.

Peng, M. W., \& Heath, P. S. (1996). The growth of the firm in planned economies in transition: Institutions, organizations, and strategic choice. Academy of Management Review, 21(2), 492-528.

Piskorski, M. (2005). Note on corporate strategy. Harvard Business School Background Note 705-449.

Prahalad, C. K., \& Bettis, R. A. (1986). The dominant logic: A new linkage between diversity and performance. Strategic Management Journal, 7(6), 485-501.

Rajan, R., Servaes, H., \& Zingales, L. (2000). The cost of diversity: The diversification discount and inefficient investment. The Journal of Finance, 55(1), 35-80.

Ramaswamy, K., Li, M., \& Veliyath, R. (2002). Variations in ownership behavior and propensity to diversify: A study of the Indian corporate context. Strategic Management Journal, 23(4), 345-358. 
Reliance. (2015). Full text of Mukesh Ambani's AGM speech on Reliance Jio. Available at: http://telecom.economic 'times.indiatimes.com $/ \mathrm{n}$ ews/3g-4g/full-text-of-mukesh-ambanis-agm-speech-on-reliancejio/47640433 (accessed 27 July 2015)

Rumelt, R. P. (1974). Strategy, structure and economic performance. Boston: Harvard University Press.

Rumelt, R. P. (1982). Diversification strategy and profitability. Strategic Management Journal, 3, 359-369.

Rumelt, R. P. (1991). How much does industry matter?. Strategic Management Journal, 12(3), 167-185.

Santalo, J., \& Becerra, M. (2008). Competition from specialized firms and the diversification-performance linkage. The Journal of Finance, 63(2), 851-883.

Schmalensee, R. (1985). Do markets differ much?. American Economic Review, 75, 341-351.

Schommer, M., Richter, A., \& Karna, A. (2019). Does the diversificationFirm performance relationship change over time? A meta-analytical review. Journal of Management Studies, 56(1), 270-298.

Singh, M., Nejadmalayeri, A., \& Mathur, I. (2007). Performance impact of business group affiliation: An analysis of the diversificationperformance link in a developing economy. Journal of Business Research, 60(4), 339-347.

Srinivasan, S., Thenmozhi, M., \& Vijayaraghavan, P. (2006). Impact of diversification strategy on firm performance: An entropy approach. The ICFAI Journal of Applied Finance, 12(11), 27-48.

Thomsen, S., \& Pedersen, T. (2000). Ownership structure and economic performance in the largest European companies. Strategic Management Journal, 21(6), 689-705. 
Varadarajan, P. (1986). Product diversity and firm performance: An Empirical Investigation. Journal of Marketing, 50(3), 45-57.

Varadarajan, P. R., \& Ramanujam, V. (1987). Diversification and performance: A reexamination using a new two-dimensional conceptualization of diversity in firms. Academy of Management Journal, 30(2), 380-393.

Volkov, N. I., \& Smith, G. C. (2015). Corporate diversification and firm value during economic downturns. The Quarterly Review of Economics and Finance, 55, 160-175.

Wan, W. P. (2005). Country resource environments, firm capabilities, and corporate diversification strategies. Journal of Management Studies, 42(1), 161-182.

Wang, S. H., Chen, C. J., Guo, A. R. S., \& Lin, Y. H. (2019). Strategy, capabilities, and business group performance: The endogenous role of industry diversification. Management Decision, 58(1), 76-97.

Wrigley, L. (1970). Divisional autonomy and diversification (Doctoral Dissertation, Harvard Business School, Boston).

Yigit, I., \& Behram, N. K. (2013). The relationship between diversification strategy and organizational performance in developed and emerging economy contexts: Evidence from Turkey and Netherlands. Eurasian Business Review, 3(2), 121-136.

Zahavi, T., \& Lavie, D. (2013). Intra-industry diversification and firm performance. Strategic Management Journal, 34(8), 978-998. 